\begin{tabular}{l|l|l} 
Jurnal Eksplorasi Akuntansi & $\begin{array}{l}\text { ISSN : 2656-3649 (Online) } \\
\text { hol. 1, No 1, Seri C, Februari 2019, Hal 334-348:/jea.ppj.unp.ac.id/index.php/jea/issue/view/3 }\end{array}$
\end{tabular}

\title{
ANALISIS PEMANFAATAN DANA CORPORATE SOCIAL RESPONSIBILITY BAGI PENERIMA BEASISWA BANK NAGARI
}

\author{
Gigih Apriatma1, Charoline Cheisviyanny ${ }^{2}$, Salma Taqwa ${ }^{3}$ \\ 1) Alumni Jurusan Akuntansi Fakultas Ekonomi Universitas Negeri Padang \\ ${ }^{2,3)}$ Jurusan Akuntansi Fakultas Ekonomi Universitas Negeri Padang \\ *Korespondensi: Gigih564@gmail.com
}

\begin{abstract}
The purposes of this research are to analyze the benefits of recipients of Scholarship CSR Funds by Bank Nagari,the feedback for Bank Nagari and the provision of target benefits of CSR Funds by Bank Nagari. The subject of this research was students who received Bank Nagari scholarship. This research was a qualitative research. The type of data used in this research were primary and secondary data. Primary data was obtained from the results of indepth interviews with students and secondary data was obtained from Bank Nagari's Annual report 2016. Data collection techniques were carried out by observation, interviews, and documentation. The results of this research indicated that the scholarship from Bank Nagari has benefits for recipients, while for feedback was directly not received by Bank Nagari, as well as for the overall awarded of scholarships was considered appropriate but there was different ways of register procedures.
\end{abstract}

Keywords : Benefits; Scholarships; CSR Bank Nagari

How to cite (APA $6^{\text {th }}$ style)

Gigih, Apriatma, Cheisviyanny, Charoline \& Taqwa, Salma (2019). Analisis Pemanfaatan Dana Corporate Social Responsibility bagi Penerima Beasiswa Bank Nagari. Jurnal Eksplorasi Akuntansi, 1(1) Seri C, 334-348.

\section{PENDAHULUAN}

Corporate Social Reponsibility adalah cerminan perusahaan yang peduli terhadap keadaan lingkungan dan masyarakat. Perusahan perlu untuk melaksanakan CSR supaya perusahan tersebut mendapatkan kepercayaan dari masyarakat untuk melakukan kegiatan usahanya. Corporate Social Responsibility adalah komitmen perusahaan untuk meningkatkan kesejahteraan komunitas melalui praktik bisnis yang baik dan mengkontribusikan sebagian sumber daya perusahaan (Kotler and Nancy, 2005).

Pada dasarnya CSR muncul akibat adanya kritikan dari masyarakat, pemerintah, dan lembaga lainnya mengenai dampak-dampak sosial dan lingkungan yang timbul dari aktivitas operasional perusahaan. Berbagai tragedi kemanusiaan dan lingkungan menjadi bukti 
ketidaktanggungjawaban perusahaan atas aktivitasnya yang hanya mengejar laba dengan mengabaikan dampak sosial dan lingkungan yang terjadi.

Peranan CSR saat ini bukan hanya sekedar kegiatan biasa, tetapi sekarang CSR ini sudah bagian dari strategi bisnis usaha yang tujuannya untuk membangun citra suatu perusahaan. CSR memiliki kemampuan untuk meningkatkan citra karena jika perusahaan menjalankan tata kelola bisnis yang baik perusahan dan mengikuti peraturan yang telah ditetapkan oleh pemerintah dengan baik maka masyarakat dan pemerintah akan memberikan dukungan positif kepada perusahaan tersebut. Citra positif ini akan menjadi asset yang sangat berharga bagi perusahaan dalam menjaga keberlangsungan hidupnya saat mengalami krisis (Kotler and Nancy, 2005). Melihat pentingnya CSR ini perusahan harus lebih efektif dan efisien dalam memilih bentuk CSR. Tujuannya CSR itu diharapkan akan menjadikan strategi bisnis yang inheren dalam perusahaan dalam menjaga dan meningkatkan daya saing melalui loyalitas dan reputasi perusahaan.

Hal ini sudah diatur dalam Undang-Undang Nomor 40 Tahun 2007 tentang Perseroan Terbatas, Lembaran Negara Republik Indonesia Tahun 2007 Nomor 106, Pasal 74, yang dimana setiap perseroan terbatas wajib melakukan tanggung jawab sosial dan lingkungan baik perusahan itu yang berkaitan dengan sumber daya alam maupun yang tidak berkaitan dengan sumber daya alam. Perusahan tidak lagi memikirkan untuk mendapatkan laba yang besar, tetapi perusahan harus memikirkan untuk menyisihkan laba perusahan dalam pelaksanaan CSR.

Disekitar lingkungan perusahaan, seperti masyarakat akan ikut merasakan dampak positif dari pelaksanaan CSR. Masyarakat yang mendapatkan perhatian dari perusahan yang berada pada lingkungannya, akan memberikan dukungan yang positif untuk perusahan dan pemberian nama baik untuk perusahan, Sehingga keuntungan atau laba dari perusahaan akan tetap terjaga (Stefania, 2008:37). Masyarakat sebagai stakeholder, berhak mendapatkan impact dari perusahaan atas keterlibatannya secara langsung ataupun tidak terhadap perusahaan yang berkegiatan atau beroperasi disekitar lingkungan masyarakat itu sendiri.

Kegiatan CSR yang dilakukan oleh perusahaan sangat beraneka ragam, dikelompokkan menjadi beberapa isu sosial, antara lain isu bidang pendidikan, kesehatan, lingkungan dan pelestarian alam, dan atau berbagai bantuan permodalan bagi masyarakat (Kotler and Nancy, 2005). Kegiatan ini dilakukan semata-mata untuk meningkatkan kualitas kehidupan masyarakat. Hal utama yang dapat dilakukan untuk meningkatkan kualitas ini adalah dengan berfokus pada kualitas Sumber Daya Manusia itu sendiri. Salah satu upaya nyata yang bisa diberikan oleh perusahaan kepada masyarakat yaitu di dalam bidang pendidikan. Pengamat pendidikan dari Universitas Negeri Padang (UNP), Sumatera Barat, Prof. Jamaris Jamna menilai kualitas pendidikan di daerah setempat belum merata, terlihat dengan hanya beberapa daerah yang memperlihatkan prestasi, sedangkan lainnya belum terlihat. Selama ini untuk pemerataan pendidikan pemerintah daerah hanya mengutamakan pembangunan, dan perbaikan sarana dan prasarana fisik, sementara bidang Sumber Daya Manusia belum terlihat.

Peran serta masyarakat atau pihak lain dalam peningkatan mutu pendidikan bahkan telah disinggung dalam UU RI No. 21 Tahun 2003 tentang Sistem Pendidikan Nasional pada Pasal 54. Peran serta tersebut meliputi peran serta organisasi profesi, pengusaha, dan organisasi kemasyarakatan dalam penyelenggaraan dan pengendalian mutu layanan pendidikan.

Terlepas dari ada atau tidaknya aturan mengenai keterlibatan perusahaan dalam bidang pendidikan, banyak perusahaan yang telah turut serta melaksanakan CSR pendidikan tersebut, khususnya oleh perusahaan-perusahaan yang bergerak di bidang perbankan. PT. Bank Pembangunan Sumatera Barat (Bank Nagari) adalah Bank Daerah yang berperan meningkatkan 
perekonomian masyarakat khususnya di Sumatera Barat. Bank Nagari telah menerapkan program CSR yang berguna untuk peningkatan kesejahteraan masyarakat, dengan melalui kegiatan CSR Bank Nagari berfokus dengan berbagai kegiatan yang dilakukannya. Baik itu kegiatan peduli pendidikan, lingkungan, kegiatan sosial, penyediaan sarana dan prasarana, serta kegiatan Community Development Pogram (CDP). Semua upaya tersebut dilakukan sebagai wujud Bakti Berkelanjutan Bank Nagari dalam mencapai visi Bersama Membina Citra Membangun Negeri. Salah satu bentuk kepedulian Bank Nagari dalam bidang pendidikan salah satunya melalui beasiswa yang diberikan. Langkah ini diawali dengan kesadaran bahwa pendidikan merupakan salah satu upaya untuk meningkatkan kesejahteran masyarakat dan bangsa dalam menyujudkan masa depan yang lebih baik.

Selama tahun 2016, Bank Nagari telah merealisasikan biaya dana CSR sebesar Rp10,03 miliar, meningkat 2,22\% dari posisi tahun 2015 sebesar Rp9,81 miliar. Bank Nagari mengeluarkan dana CSR terbesar pada bidang pendidikan, dengan dana yang dikeluarkan sebesar Rp. 2,57 Miliar (Anual Report 2016). Dari data CSR yang direalisasikan oleh Bank Nagari, bidang pendidikan adalah bagian terbesar alokasi dana CSR pada tahun 2016. Hal yang sama terjadi lima tahun sebelumnya, dana CSR yang besar dikeluarkan oleh Bank Nagari dibidang pendidikan. Dilihat dari perbankan lainnya. seperti, Bank Danamon, Bank BRI, Bank Muamalat, ketiga bank tersebut tidak banyak mengeluarkan dana CSR dibagian pendidikan, hanya dibidang pemberdayaan masyarakat dan peduli lingkungan. Hal ini tentu menarik untuk dikaji peneliti lebih dalam kenapa Bank Nagari ini lebih berfokus kepada bidang pendidikan melalui beasiswa.

Berdasarkan data annual report Bank nagari tahun 2016, menyajikan data CSR yang direalisasikan oleh Bank Nagari, bidang pendidikan adalah bagian terbesar alokasi dana CSR pada tahun 2016. Hal ini akan sangat membantu masyarakat yang menerima dana CSR yang dikeluarkan Bank Nagari. Kondisi ini akan tercapai jika penerima dana CSR dapat menggunakan dana yang diberikan secara efektif dan efesien. Serta akan membantu program pemerintah dalam meningkatkan pendidikan khususnya di daerah Sumatera Barat.

Penelitian terdahulu yang diteliti oleh Zona (2013) yang berjudul Bentuk Program Corporate Social Responsibility Bank Nagari Cabang Pangkalan dan Manfaatnya Bagi kehidupan Sosial Ekonomi Masyarakat Sosial di bidang pendidikan, keagamaan, kebudayaan, seni dan olahraga, dan sosial. Dimana hasil dari program CSR Bank Nagari dapat memberikan manfaat bagi kehidupan sosial ekonomi masyarakat lokal pada saat program tersebut diselenggarakan oleh pihak Bank Nagari. Akan tetapi, program-program CSR Bank Nagari Cabang Pangkalan tidak memberikan manfaat jangka panjang bagi kehidupan sosial ekonomi masyarakat lokal.

Penelitian ini dilakukan untuk melihat bagaimana manfaat yang dirasakan penerima dana beasiswa dan apakah Bank Nagari sudah tepat sasaran atau sudah sesuai dengan prosedur yang ditetapkan dalam pemberian dana CSR tersebut, serta timbal balik yang di rasakan Bank Nagari dari penyaluran dana CSR tersebut. Berdasarkan uraian tersebut, peneliti tertarik untuk melakukan penelitian dengan judul, "Analisis Pemanfaatan Dana Corporate Social Responsibility Bagi Penerima Beasiswa Bank Nagari."

\section{REVIU LITERATUR DAN HIPOTESIS}

\section{Teori Stakeholder}

Teori Stakeholder mengasumsikan bahwa eksistensi perusahaan memerlukan dukungan stakeholder, sehingga aktivitas perusahaan juga mempertimbangkan persetujuan dari stakeholder. Semakin kuat stakeholder, maka perusahaan harus semakin beradaptasi dengan 
stakeholder. Pengungkapan sosial dan lingkungan kemudian dipandang sebagai dialog antara perusahaan dengan stakeholder.

Stakeholder menurut Budi (2008) adalah semua pihak baik internal maupun eksternal yang memilki hubungan baik dengan bersifat mempengaruhi maupun dipengaruhi, bersifat langsung maupun tidak langsung terhadap perusahaan. Jadi stakeholder merupakan pihak internal maupun eksternal, seperti: pemerintah, perusahaan pesaing, masyarakat sekitar, lingkungan internasional, lembaga di luar perusahaan, lembaga pemerhati lingkungan, para pekerja perusahaan, kaum minoritas dan lain sebagainya yang keberadaannya sangat mempengaruhi dan dipengaruhi oleh perusahaan.

Menurut Rochayatun (2017), esensi teori stakeholder jika ditarik interkoneksi dengan teori legitimasi yang mengisyaratkan bahwa perusahaan hendaknya mengurangi expection gap dengan masyarakat (publik) sekitar guna meningkatkan legitimasi (pengakuan) ternyata terdapat benang merah. Untuk itu, prusahaan hendaknya menjaga reputasinya dengan menggeser pola orientasi (tujuan) yang semata-mata diukur dengan economic measurement yang cenderung shareholder orientation, ke arah yang memperhitungkan sosial (social factor), sebagai wujud kepedulian dan keberpihakan terhadap masalah sosial kemasyarakatan (stakeholder orientation).

\section{Corporate Sosial Responsibility}

The World Business Council for Sustainability Development (WBCSD) dalam Suharto (2010) mendefinisikan CSR sebagai "Komitmen berkesinambungan dari kalangan bisnis untuk berperilaku etis dan memberi kontribusi bagi pembangunan ekonomi, supaya meningkatkan kualitas kehidupan karyawan dan keluarganya, serta komunitas lokal dan masyarakat luas pada umumnya.'Definisi lain dari Institute of Chartered Accountants, England and Wales dalam Suharto (2010) menyatakan CSR merupakan "Jaminan bahwa organisasi-organisasi pengelola bisnis mampu memberi dampak positif bagi masyarakat dan lingkungan seraya memaksimalkan nilai bagi para pemegang saham (shareholders) mereka."

Definisi CSR menurut Kotler (2005) dalam Kurniawan (2013), yaitu sebagai komitmen perusahaan yang secara sukarela ingin mengembangkan kesejahteraan masyarakat melalui praktik bisnis dan kontribusi sumber daya perusahaan. Adapun Lawrence dan Weber (2008) dalam Putra (2012) berpendapat bahwa CSR berarti perusahaan harus bertanggung jawab terhadap kegiatannya yang mempengaruhi masyarakat, komunitas, dan lingkungan. Berdasarkan beberapa definisi di atas disimpulkan bahwa CSR merupakan sebuah tindakan perusahaan untuk memaksimalkan nilai bagi pemegang saham dengan melakukan praktik bisnis yang sesuai dengan etika dan membantu kehidupan lingkungan, ekonomi, dan kesejahteraan masyarakat. Adanya CSR mendorong perusahaan lebih mengedepankan sustainability dari pada profitabilitas perusahaan yang akan berdampak positif pada perusahaan.

Menurut Wibisono (2007), dari segi perusahaan terdapat berbagai manfaat yang dapat diperoleh dari aktivitas CSR seperti (1) mengurangi resiko dan tuduhan terhadap perlakuan tidak pantas yang diterima perusahaan, (2) perlindungan dan membantu perusahaan meminimalkan dampak buruk yang diakibatkan suatu krisis, (3) ketertiban dan kebanggaan karyawan, (4) memperbaiki dan mempererat hubungan perusahaan, (5) meningkatkan jumlah penjualan, (6) insentif-insentif lainnya.

Bidang pendidikan merupakan salah satu pilihan program CSR yang harus mendapatkan perhatian perusahaan. Elkington (1997) merangkum definisi CSR dalam suatu konsep 3P, yaitu suatu bentuk kepedulian perusahaan yang menyisihkan sebagian keuntungannya (profit) bagi 
kepentingan pembangunan manusia (people) dan lingkungan (planet). Konsep people merujuk pada konsep social development dan human rights yang menyangkut kesejahteraan ekonomi dan kesejahteraan sosial masyarakat. Beberapa bentuk pelaksanaan konsep ini diantaranya pelatihan keterampilan kerja, pemberian jaminan sosial, penguatan aksesibilitas masyarakat terhadap pelayanan pendidikan, penguatan kapasitas lembaga-lembaga sosial, kesehatan dan kearifan lokal (Marlia, 2008). Peningkatan akses masyarakat terhadap pendidikan yang lebih berkualitas merupakan mandat yang harus dilakukan bangsa Indonesia sesuai dengan tujuan negara Indonesia yang tertuang dalam Pembukaan UUD 1945 yaitu untuk melindungi segenap bangsa dan seluruh tumpah darah Indonesia, mencerdaskan kehidupan bangsa, memajukan kesejahteraan umum dan ikut melaksanakan ketertiban dunia yang berdasarkan kemerdekaan, perdamaian abadi dan keadilan sosial. Lebih lanjut dalam Batang Tubuh UUD 1945 diamanatkan pentingnya pendidikan bagi seluruh warga negara seperti yang tertuang dalam Pasal 28B Ayat (1) yaitu bahwa setiap orang berhak mengembangkan diri melalui pemenuhan kebutuhan dasarnya, berhak mendapatkan pendidikan dan mendapatkan manfaat dari ilmu pengetahuan dan teknologi, seni dan budaya demi meningkatkan kualitas hidupnya demi kesejahteraan umat manusia, dan Pasal 31 Ayat (1) yang mengamanatkan bahwa setiap warga Negara berhak mendapat pendidikan (www.bappenas.go.id).

Peranan perusahaan dalam bidang pendidikan sangat dibutuhkan untuk meningkatkan kualitas pendidikan. Kepekaan perusahaan terhadap dunia pendidikan merupakan investasi dan dapat memberikan manfaat secara berkesinambungan. Berbagai hal permasalahan mengenai pendidikan salah satunya adalah kemiskinan. Kemiskinan timbul akibat perbedaan kemampuan, perbedaan, kesempatan, dan perbedaan sumberdaya. Akibat dari kemiskinan menimbulkan dampak negatif yang sangat besar diantaranya adalah timbulnya kejahatan, karena orang yang berada dalam kemiskinan tidak dapat melaksanakan berbagai kehidupan sosialnya dengan baik, tidak dapat memperoleh pendidikan yang baik, akses kesehatan yang berkualitas,melaksanakan kewajiban agama secara maksimal, dan merasakan hidup yang layak.

\section{BEASISWA}

Beasiswa memiliki arti sebagai bantuan yang diberikan pada mahasiswa dalam bentuk dana atau uang yang akan digunakan untuk membantu proses pendidikan. Sesuai dengan terminolgy dalam Kamus Besar Bahasa Indonesia, beasiswa adalah "tunjangan yang diberikan kepada pelajar dan mahasiswa sebagai bantuan biaya belajar". Beasiswa dimaksudkan sebagai bantuan yang diberikan pada mahasiswa dalam bentuk dana atau berupa uang yang dapat digunakan untuk membantu keperluan proses pendidikan. Beasiswa dapat diberikan oleh lembaga pemerintah, perusahaan ataupun yayasan. Pemberian beasiswa dapat dikategorikan pada pemberian cumacuma ataupun pemberian dengan ikatan kerja (biasa disebut ikatan dinas) setelah selesainya pendidikan. Lama ikatan dinas ini berbeda-beda tergantung pada lembaga yang memberikan beasiswa tersebut. Beasiswa juga ditujukan untuk mengantisipasi mahalnya memperoleh pendidikan yang diharapkan memenuhi segala kebutuhan dalam proses belajar agar pendidikan dapat dilaksanakan dengan baik.

Syarat- syarat penerima beasiswa Bank Nagari adalah (1) terdaftar sebagai mahasiswa aktif, (2) surat Keterangan Kurang Mampu dari Kelurahan bagi orangtua Non PNS dan perincian gaji terbaru bagi orang tuanya PNS, (3) indeks Prestasi Kumulatif (IPK) minimal 3,00, (4) historis nilai asli dan fotokopi, (5) surat keterangan kelakukan baik dari Pembantu Dekan III, (6) Fotokopi kartu keluarga, (7) Fotokopi nomor rekening Bank Nagari (aktif dan atas nama sendiri) 


\section{KERANGKA KONSEPTUAL}

Kerangka konseptual penelitian ini menggambarkan alur penelitian yang dimulai dari CSR kemudian menganalisis tiga masalah dalam penelitian sehingga ditarik sebuah kesimpulan. Dapat dilihat pada gambar berikut ini:

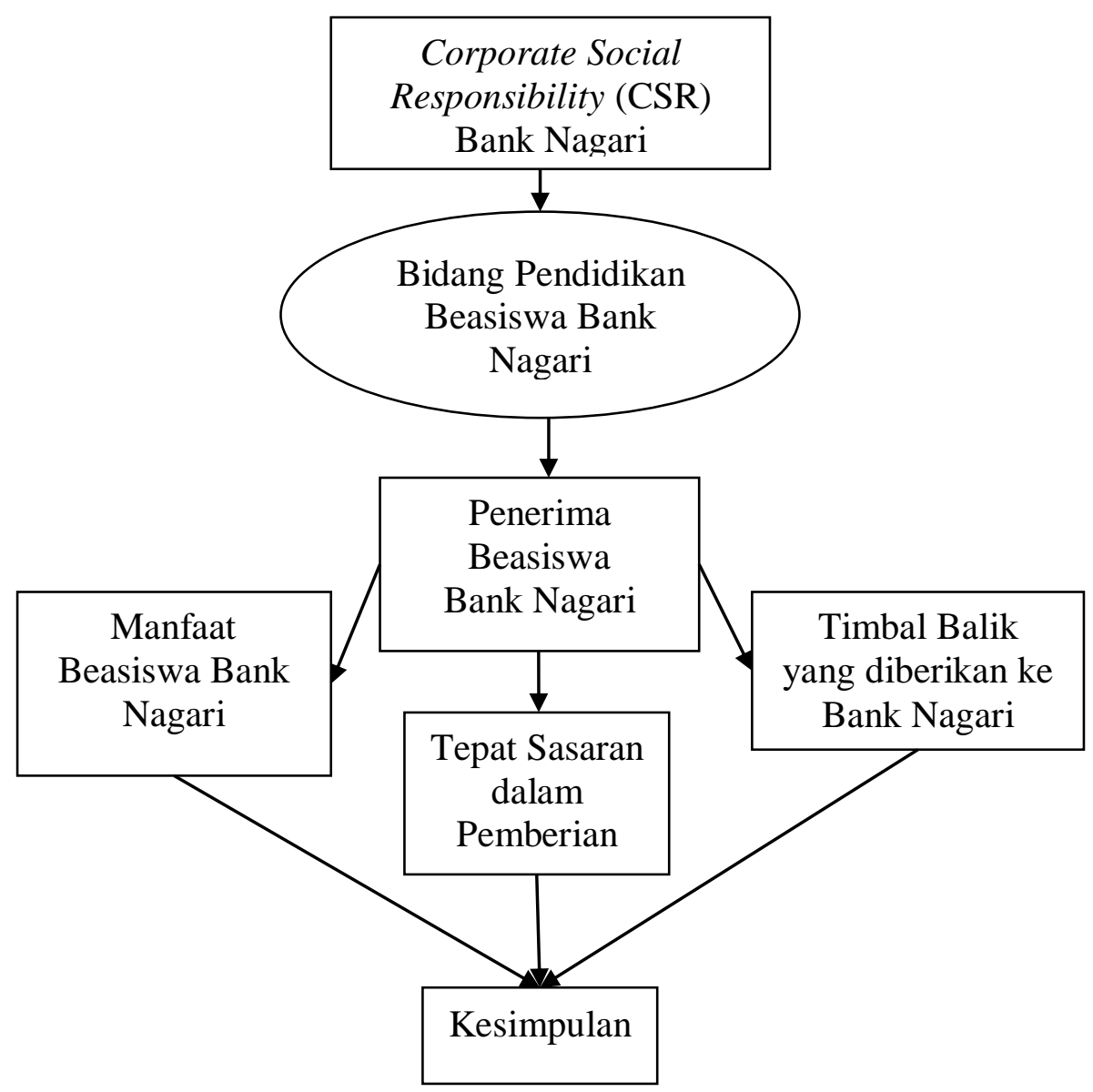

\section{METODOLOGI PENELITIAN}

\section{Jenis Penelitian}

Jenis penelitian yang digunakan adalah penelitian kualitatif interpretif. Penelitian kualitatif adalah penelitian yang berlandaskan pada filsafat postpositivisme, digunakan untuk meneliti pada kondisi objek yang alamiah, dimana peneliti adalah sebagai instrument kunci, teknik pengumpulan data dilakukan secara triangulasi. Analisis data bersifat induktif dan hasil penelitian kualitatif lebih menekankan makna dari generalisasi (Sugiyono 2014).

Metode interpretif memberikan gambaran yang luas akan konteks penelitian, prosesnya secara interaktif dan makna yang tidak terukur oleh data statistic, berupaya merumuskan suatu pertanyaan yang kemudian dianalisis berdasarkan pada pertanyaan persepsi partisipan yang diteliti. Dalam metode ini peneliti menggunakan teknik triangulasi sumber data. Triangulasi sumber data merupakan pengecekan data dari berbagai sumber dengan berbagai cara dan berbagai waktu (Sugiyono 2012). Peneliti melakukan teknik triangulasi dengan mencocokkan dan 
menyatukan semua data yang diperoleh dari teknik observasi, wawancara mendalam dan dokumen yang telah terkumpul.

\section{Jenis Data}

Jenis data yang digunakan dalam penelitian ini ada dua jenis, yaitu:

a. Data primer, yaitu pengambilan data yang dilakukan langsung oleh peneliti terhadap informan yang dilakukan dengan wawancara mendalam. Wawancara mendalam dilakukan terhadap informan atau narasumber yang memahami konteks masalah yang sedang diteliti. Selain wawancara peneliti juga menggunakan data sekunder dengan cara pengumpulan data dokumentasi dan observasi, serta dengan pengumpulan data dari berbagai sumber yang dikenal sebagai triangulasi.

b. Data sekunder, yaitu data yang diperoleh secara tidak langsung atau yang didapat dari pihak ketiga atau literatur, tulisan, dokumentasi, tulisan-tulisan sebagai pembanding dari data yang diperoleh yaitu buku-buku referansi, undang-undang dan media lainnya.

\section{Sumber Data}

Dalam penelitian ini sumber data yang diperoleh yaitu melalui informasi yang ditentukan menggunakan wawancara. Menurut Sugiyono (2012), pengambilan sumber data diambil secara purposive, yaitu teknik penentuan sampel dengan pertimbangan tertentu atau digunakan karena peneliti menentukan sendiri sampel yang diambil karena pertimbangan tertentu. Penelitian ini dilakukan pada mahasiswa yang pernah menerima CSR Beasiswa Bank Nagari di Fakultas Ekonomi Universitas Negeri Padang. Narasumber yang di pilih dalam penelitian ini yaitu 9 orang yang pernah menerima beasisiwa dari Bank Nagari dan salah satu informan yang tidak lulus.

\section{Instrumen Penelitian}

Alat yang digunakan untuk pengumpulan data pada penelitian ini adalah peneliti sendiri dengan menggunakan alat bantuan panduan wawancara, panduan observasi dan pengambilan dokumentasi. "penelitian kualitatif sebagai human instrument, berfungsi menetapkan fokus masalah, memilih informan sebagai sumber data, menafsirkan data dan membuat kesimpulan atas temuannya"(Sugiyono 2012). Peneliti turun langsung ke lapangan melakukan wawancara, panduan observasi dan pengambilan dokumentasi. Menurut Afrizal (2014:134) instrumen penelitian adalah alat-alat yang diperlukan atau yang dipergunakan untuk mengumpulkan data. Dalam penelitian kualitatif, alat atau instrumen utama dalam pengumpulan data adalah manusia yaitu peneliti sendiri.

\section{Teknik Pengumpulan Data}

Teknik pengumpulan data yang digunakan dalam penelitian ini adalah sebagai berikut (Sugiyono 2012):

\section{Wawancara semistruktur}

Dalam penelitian wawancara memegang peran penting, karena metode wawancara digunakan peneliti untuk mengumpulkan data dan memperoleh informasi. Wawancara semiterstruktur adalah wawancara dimana pelaksanaannya lebih bebas untuk menemukan permasalahan secara lebih terbuka kepada pihak yang diajak wawancara diminta pendapat dan ide-idenya. Penulis menggunakan teknik wawancara semiterstruktur, karena wawancara semiterstruktur sudah 
termasuk dalam kategori in-depth interview, dimana dalam pelaksanaannya lebih bebas bila dibandingkan dengan wawancara terstruktur (Sugiyono 2012). Subyek yang diwawancara pada penelitian ini dikhususkan pada penerima beasiswa Bank Nagari.

\section{Observasi}

Menurut Nazir (2013) observasi merupakan pengumpulan data langsung dari lapangan. Observasi langsung atau pengamatan secara langsung adalah cara pengambilan data dengan menggunakan mata tanpa ada pertolongan alat standar lain untuk keperluan tersebut. Adapun kriteria observasi langsung adalah sebagai berikut:

a. Pengamatan digunakan untuk penelitian dan telah direncanakan secara sistematik.

b. Pengamatan harus berkaitan dengan tujuan penelitian yang telah direncanakan.

c. Pengamatan tersebut dicatat secara sistematis dan dihubungkan dengan proporsi umum dan bukan dipaparkan sebagai suatu set yang manarik perhatian saja.

d. Penelitian dapat ditelusuri dan dikontrol atas validitas dan realibilitas.

\section{Analisis Dokumentasi}

Teknik pengumpulan sekunder data dengan berbagai sumber yang ada diluar. Dokumentasi yang diperlukan dalam pemanfaatan dana CSR yaitu data penerima beasiswa dari dana CSR Bank Nagari. Analisis dokumen digunakan sebagai sumber data yang dapat mendukung data dari wawancara dan observasi.

\section{Teknik Analisis Data}

Analisis data merupakan proses mencari dan menyusun secara sistematis data yang diperoleh dari hasil wawancara, catatan lapangan dan bahan-bahan lain, sehingga dapat mudah dipahami dan temuannya dapat diinformasikan kepada orang lain (Sugiyono 2012). Pada penelitian ini tahaptahap analisis data dilakukan untuk menentukan kategori, konsep, tema dan pola serta terakhir melakukan analisis data. Langkah-langkah dalam menganalisis data metode interpretif yaitu:

1. Data dikumpulkan dengan menggunakan wawancara semi-terstruktur dengan mengikuti panduan wawancara yang berfungsi memastikan bahwa masalah relevan ditanyakan kepada informan. Pengumpulan data dari berbagai sumber yang dikenal sebagai triangulasi data.

2. Wawancara akan direkam dengan izin dari informan, untuk memastikan akurasi data wawancara yang dikumpulkan dan dianalisis nantinya.

3. Selama pengumpulan data peneliti akan mengelola catatan lapangan dan hasil wawancara dengan berusaha untuk tidak mendistorsikan makna dari tanggapan narasumber selama proses pengumpulan data.

4. Hasil wawancara ditranskip dan dianalisis secara individual.

5. Coding data wawancara disesuaikan dengan tema utama dari kerangka konseptual yang ada dalam penelitian untuk memastikan konsistensi wawancara. Selanjutnya, tema utama dalam penelitiaan ini dipecah lagi menjadi tema-tema yang lebih khusus/detail dengan mengidentifikasi topic khusus yang berkaitan erat dengan tema utama. Data pada penelitian ini dikaitkan dengan theoretical framework yang ada sehingga interpretasi tidak bersifat bias tetapi dapat dijelaskan oleh teori tersebut. Dalam melakukan interpretasi, penelitian ini juga tidak terlepas dari kejadian yang ada pada setting penelitian. Setelah ditemukan bukti yang mendukung dan konsistensi di lapangan dapat menjawab rumusan masalah yang dirumuskan, maka barulah dibuat kesimpulan yang sebenarnya sehingga hasil penelitian jelas maksud dan tujuannya. 


\section{HASIL PENELITIAN}

\section{Manfaat yang dirasakan penerima beasiswa}

Hasil penelitian ini akan menganalisis manfaat yang diterima oleh penerima beasiswa Bank Nagari. Pelaksanaan program CSR Bank Nagari bertujuan untuk membantu masyarakat kurang mampu. Pada realisasinya beasiswa ini memberikan manfaat bagi sebagian masyarakat. Manfaat yang dirasakan langsung oleh penerima adalah dapat mengurangi beban keluarga dalam pembiayaan pendidikan, dapat memotivasi agar mendapatkan prestasi yang baik.

\section{Membantu mengurangi biaya pendidikan}

Pendidikan adalah suatu hal yang sangat penting bagi semua orang apalagi dizaman yang modern ini, pendidikan adalah hal yang mutlak dan harus didapatkan oleh semua orang jika tidak ingin tertinggal dan terbelakangi dizaman modern ini. Saat ini sudah banyak cara untuk mendapatkan pendidikan dengan cara mendapatkan beasisiwa. Bagi sebagaian masyarakat yang kurang mampu dalam membiayai pendidikan, melalui beasiswa ini masyarakat bisa terbantu mengurangi biaya pendidikan. CSR Bank Nagari dibidang pendidikan memberikan kontribusi untuk meringankan beban orang tua dalam biaya pendidikan.

berikut ini:

Seperti yang diungkapkan oleh Isma, salah seorang penerima beasiswa Bank Nagari

"beasiswa ini dirasa sangat membantu dalam proses perkuliahan karena dapat meminimalisir biaya orang tua untuk kebutuhan perkuliahan seperti membeli buku, biaya foto copy bahan kuliah, dan memberikan semangat untuk mendapatkan nilai yang bagus".

Hal yang sama juga diungkapkan oleh Sri selaku penerima beasiswa bank nagari, seperti berikut ini:

"Manfaat yang saya rasakan dari beasisiwa ini, membuat saya lebih bersemangat dan bersyukur dapat meringankan biaya untuk sekedar membeli perlengkapan kuliah".

Dari hasil ini dapat disimpulkan bahwa sebagai pihak perbankan yang telah melaksanakan CSR Bank Nagari secara langsung telah membantu pemerintah dalam proses peningkatan pendidikan khususnya didaerah Sumatera Barat. Undang-Undang Republik Indonesia Nomor 20 Tahun 2003 tentang Sistem Pendidikan Nasional, Bab V pasal 12 (1.c), menyebutkan bahwa setiap peserta didik pada setiap satuan pendidikan berhak mendapatkan beasiswa bagi yang berprestasi serta orang tuanya kurang mampu untuk membiayai pendidikannya. Pemerintah sendiri telah mengeluarkan sebuah program bantuan biaya pendidikan bagi masyarakat kurang mampu yang dikenal dengan nama beasiswa bidikmisi.

Bidikmisi adalah bantuan biaya pendidikan, berbeda dari beasiswa yang berfokus pada memberikan penghargaan atau dukungan dana terhadap mereka yang berprestasi, bidikmisi berfokus kepada yang memiliki keterbatasan kemampuan ekonomi (Pasal 76 UU No. 12 Tahun 2012 tentang Pendidikan Tinggi). Bidikmisi hanya diberikan pada pihak yang benar-benar memenuhi syarat untuk mendapatkannya. Sehingga, tidak semua calon mahasiswa mendapatkan bantuan biaya pendidikan ini. CSR Bank Nagari berupa beasiswa ini adalah salah satu alternatif untuk membantu biaya pendidikan, karena hal ini juga dapat meringankan beban orang tua yang kurang mampu dalam membiaya pendidikan anaknya. 


\section{Upaya dalam meningkatkan motivasi belajar}

Motivasi belajar adalah keseluruhan daya penggerak psikis dalam diri siswa yang menimbulkan kekuatan belajar mengajar, kelangsungan belajar itu demi mencapai suatu tujuan. (Suardi, 2015:44) Motivasi belajar tidak selalu datang dengan sendirinya dari dalam diri. Motivasi belajar dapat dipengaruhi oleh banyak faktor baik itu dari dalam maupun dari luar. Pelaksanaan program CSR Bank Nagari merupakan angin segar bagi mahasiswa yang memiliki prestasi namun belum tersentuh beasiswa. Serta program ini juga membuat motivasi belajar dan peningkatan kemampuan mahasiswa menjadi lebih tinggi. Seperti yang diungkapkan oleh Suzila berikut ini:

\section{"Beasiswa yang saya dapatkan ini membuat saya berusaha meningkatkan prestasi belajar agar dapat meningkatkan IPK dan menyelesaikan perkuliahan tepat waktu."}

Pemberian beasiswa dari Bank Nagari begitu berpengaruh terhadap mahasiswa, karena dapat memotivasi diri untuk mendapatkan prestasi yang lebih baik kedepannya. Secara langsung Bank Nagari sudah berkontribusi dalam dunia pendidikan yang lebih berkualitas. Mendorong dan mempertahankan semangat belajar mahasiswa sehingga mampu tetap berprestasi dan berpacu dalam menyelesaikan studi. Mendorong mencapai prestasi akademik yang tertinggi sehingga sumberdaya manusia yang potensial tersebut tidak sia-sia.

Penelitian ini didukung oleh penelitian Debi tahun 2014 dengan judul "Hubungan Motivasi Belajar dengan Prestasi Belajar pada Mahasiswa Bidikmisi Jurusan Ekonomi dan Administrasi Universitas Negeri Jakarta" memberikan kesimpulan bahwa adanya hubungan yang positif antara motivasi belajar dengan prestasi belajar mahasiswa penerima beasiswa Bidikmisi program studi Pendidikan Ekonomi UNJ.

\section{Kurangnya dana beasiswa yang diberikan}

Selain manfaat yang dijelaskan diatas terdapat beberapa keluhan yang dirasakan dari penerima beasiswa tersebut yaitu dari segi jumlah dana yang diberikan oleh Bank Nagari ini. Bank Nagari memberikan beasiswa sebesar 2.500 .000 dalam satu tahun, setiap semester beasiswa diberikan sebesar 1.250.000. nominal tersebut dirasa kurang cukup serta kuota beasiswa yang diberikan juga kurang. Karena hanya bisa dipergunakan untuk membeli keperluan kuliah saja. Hal ini diperkuat oleh penerima beasiswa sebagai berikut:

"Saya rasa kurang, kalau bisa dana yang diberikan Rp. 3.000.000-Rp. 4.000.000 karena mahasiswa yang masuk lewat jalur mandiri mempunyai UKT rata-rata Rp. 3.000.000- Rp. 4.000.000."

CSR Bank Nagari ini menurut Zona (2013) program CSR Bank Nagari Cabang Pangkalan bersifat filantropi (kedermawanan) yang tertuang dalam bentuk sumbangan yang diberikan kepada masyarakat kurang mampu serta sumbangan dalam berbagai acara yang diselenggarakan oleh masyarakat lokal.

“Community Development Program (CDP) merupakan salah satu bentuk tindakan CSR yang dikembangkan oleh Bank Nagari, baik berpartisipasi langsung dalam kegiatan atau bertindak sebagai sponsorship".(Annual Report 2016) 
Hal ini membuat beasiswa yang diberikan tidak terlalu besar dan Bank Nagari memberikan beasiswa hanya sebagai bentuk apresisasi kepada mahasiswa berprestasi dari keluarga yang kurang mampu. Jika dilihat dari hasil wawancara diatas, maka diharapkan Bank Nagari bisa memberikan beasiswa sesuai dengan kebutuhan dari calon penerima beasiswa.

Berdasarkan wawancara dan pengamatan langsung bahwa program CSR beasiswa Bank Nagari ini memberikan manfaat berkurangnya beban ekonomi bagi mahasiswa yang kurang mampu untuk sementara waktu. Hal ini bisa membantu orang tua dalam membiayai pendidikan yang lebih baik. Program beasiswa Bank Nagari ini membuat motivasi belajar mahasiswa meningkat karena pemberian beasiswa Bank Nagari untuk satu tahun masa studi, Sehingga mahasiswa mentingkatkan motivasi belajar untuk mendapatkan beasiswa.

\section{Timbal balik yang dirasakan Bank Nagari dari penyaluran dana CSR Sebagai startegi bisnis}

Pada dasarnya, setiap pemberian beasiswa pasti memiliki tujuan dan manfaat. Tanpa terkecuali CSR yang dikeluarkan oleh Bank Nagari untuk bantuan biaya pendidikan di wilayah Sumatera Barat. Walau kuantitas yang diberikan hanya bisa menutupi sebagian biaya pendidikan khususnya di perguruan tinggi. Namun, setidaknya Bank Nagari sudah berkontribusi dalam membantu masyarakat mengurangi beban finansial dan menciptakan sumberdaya manusia yang berkualitas dengan harapan pendidikan yang lebih tinggi.

Beasiswa Bank Nagari diharapkan dapat terus berjalan agar dapat membantu mahasiswa serta pelajar yang kurang mampu. Meskipun Bank Nagari tidak menuntut lebih kepada penerima beasiswa selain tetap bisa mempertahankan prestasi di bidang akademik khususnya IPK.

Dikutip dari sebuah artikel salah satu Universitas penerima beasiswa Bank Nagari, yang disampaikan langsung oleh Direktur Utama Bank Nagari Dedy Ihsan, SE, Master of Business (B\&F) menyampaikan dengan diberikannya bantuan biaya pendidikan ini, harapannya mahasiswa dapat lebih giat belajar dan terus produktif. Selain itu juga dapat memotivasi agar mahasiswa setelah tamat nantinya dapat berkarir di Bank Nagari. Kedepannya Bank Nagari akan melakukan rekuitmen secara langsung ke kampus-kampus untuk mencari lulusan terbaik. Semoga kerja sama ini dapat terus ditingkatkan.

Berdasarkan pengamatan peneliti bahwa pelaksanaan program CSR Bank Nagari dibidang pendidikan ini hanya sebagai menjaga citra perusahan dan mendapat dukungan antara lain masyarakat, mitra bisnis dan pihak yang berkepentingan demi kelangsungan perusahan. Hal ini sesuai dengan teori stakeholder bahwa eksistensi perusahaan memerlukan dukungan stakeholder. Stakeholder menurut Budi (2008) adalah semua pihak baik internal maupun eksternal yang memilki hubungan baik dengan bersifat mempengaruhi maupun dipengaruhi, bersifat langsung maupun tidak langsung terhadap perusahaan.

\section{Tepat sasaran dalam pemberian beasiswa Bank Nagari Prosedur penyaluran beasiswa Bank Nagari}

Sasaran awal dari beasiswa ini adalah golongan masyarakat yang tidak mampu dari segi ekonomi, agar mereka tetap bisa mengenyam pendidikan yang layak. Tujuan utama adalah meningkatkan motivasi belajar dan prestasi mahasiswa, khususnya mereka yang menghadapi kendala ekonomi, meningkatkan akses dan kesempatan belajar di perguruan tinggi bagi peserta didik yang berpotensi akademik memadai dan kurang mampu secara ekonomi.

Bank Nagari memberikan bantuan dana beasiswa kepada pemerintah daerah, universitas yang ada di Sumatera Barat dan beberapa anak karyawan Bank Nagari yang berprestasi (Annual 
Report 2016). Bank Nagari tidak terlibat langsung dalam proses pemberian beasiswa tersebut, karena yang mengelola dan menyeleksi untuk siapa beasiswa itu diberikan yaitu pihak universitas atau pemda yang telah ditentukan oleh pihak bank sendiri. Hal ini menyebabkan proses pengelola dan seleksi dalam pemberian beasiswa kurang berjalan dengan baik. Hal ini diperkuat dari salah satu mahasiswa Efril yang tidak lulus beasiswa Bank Nagari:

"“IPK minimal harus 3 sebagai syarat peserta pendaftaran beasiswa, dengan IPK yang lebih dari 3 tapi saya tidak lulus. Saya sudah lebih dua kali mendaftar dan mengikuti prosedurnya tapi tetap tidak diterima. '"

Peneliti menemukan mahasiswa lain yang juga gagal mendapatkan beasiswa Bank Nagari. Dalam proses prosedur pendaftaran pada umumnya, calon penerima beasiswa harus melengkapi syarat-syarat yang telah ditetapkan terlebih dahulu. Calon penerima mengurus surat keterangan tidak mampu ke pihak terkait karena beasiswa ini ditujukan kepada mahasiswa kurang mampu dan berprestasi dibidang akademik. Berikut syarat-syarat beasiswa Bank Nagari:

1. Terdaftar sebagai mahasiswa aktif

2. Surat Keterangan Kurang Mampu dari Kelurahan bagi orangtua Non PNS dan perincian gaji terbaru bagi orang tuanya PNS.

3. Indeks Prestasi Kumulatif (IPK) minimal 3,00 (tiga koma nol nol)

4. Historis nilai

5. Surat keterangan kelakukan baik dari Pembantu Dekan III

6. Fotokopi nomor rekening Bank Nagari

Setelah melengkapi syarat diatas calon penerima menyerahkan kepada pihak kampus dan mengisi formulir yang telah disediakan oleh pihak kampus. Menurut informan yang peneliti waawancara sedikit berbeda cara pendaftarannya, karena pendaftaran tidak sesuai dengan prosedur pendaftaran yang telah ditetapkan. Menurut keterangannya mahasiswa yang tidak lulus dari beasiswa bidik misi langsung dialihkan ke beasiswa Bank Nagari dan tidak ada pengumuman untuk beasiswa ini. Hal ini diperkuat oleh mahasiswa yang tidak lulus Mariani:

“...yang tidak lulus bidik misi langsung dialihkan ke beasiswa Bank Nagari. Syarat yang diminta nama, nim, foto rumah dan foto kegiatan kuliah umum tentang beasiswa."

Hal yang sama juga dikatakan oleh Rany mahasiswa yang lulus beasiswa tetapi belum mendapatkan beasiswa tersebut.

“...bagi yang daftar bidik misi dan tidak lulus langsung pihak kampus yang mengalihkan ke beasiswa ini. Saya tidak pernah mendaftar beasiswa Bank Nagari dan melngkapi syarat-syaratnya."

Peluang dari mahasiswa lain yang memiliki prestasi menjadi sedikit karena tidak adanya pemberitahuan tentang beasiswa Bank Nagari. Sedikitnya kouta penerima beasiswa Bank Nagari dan tidak ada pengumuman akan terjadi kesalahan dalam penyaluran dana beasiswa ini. Diharapkan beasiswa Bank Nagari lebih konsisten tiap tahunnya dalam proses prosedur penerimaan beasiswa Bank Nagari agar mahasiswa yang lainnya dapat kesempatan memperoleh beasiswa Bank Nagari. Hal ini perlu pengawasan dalam pemberian beasiswa sehingga beasiswa 
ini akan lebih tepat sasaran dalam pemberiannya. Diharapkan proses memberikan beasiswa kedepannya bisa lebih baik lagi agar tidak terjadi kesalahan dalam pendistribusian beasiswa tersebut dan menambahkan kouta penerima beasiswa supaya mahasiswa dapat menerima beasiswa tersebut.

Menurut peneliti secara keseluruhan penyaluran dan program CSR Bank Nagari dibidang pendidikan telah sesuai dengan prosedurnya. Tetapi ada perbedaan yang muncul pada proses pendaftaran untuk mendapatkan beasiswa ini. Dimana beberapa mahasiswa ada yang menyiapkan langsuang syarat beasisiwa dan ada pula yang tidak menyiapkan syarat-syarat pendaftaran karena pihak pengelola yang mengambil alih untuk mendaftarkan mahasiswa nya.

\section{SIMPULAN, KETERBATASAN DAN SARAN}

Simpulan

Penelitian ini menganalisis manfaat penerima beasiswa Bank Nagari di Padang. Berdasarkan hasil wawancara dan pengamatan langsung oleh peneliti lakukan program CSR bank Nagari dibidang pendidikan yaitu beasiswa dapat disimpulkan:

1. Penerima beasiswa tersebut merasakan manfaatnya dalam mendapatkan pendidikan yang lebih tinggi. Program CSR Bank Nagari ini membantu mahasiswa atau pelajar untuk meningkatkan motivasi dalam proses belajar supaya berlomba-lomba untuk mendapatkan prestasi yang tinggi dan mendapatkan kesempatan beasiswa kedepannya dan membantu meringankan biaya pendidikan.

2. Ada program CSR Bank Nagari bidang Pendidikan ini dampak yang dirasakan bahwa untuk terciptanya hubungan yang serasi dan seimbang antara Bank dengan lingkungan dan masyarakat setempat. Hal ini untuk menjaga citra perusahan dan mendapat dukungan antara lain masyarakat, mitra bisnis dan pihak yang berkepentingan.

3. Penyaluran beasiswa Bank Nagari secara keseluruhan sudah baik namun terdapat perbedaan dalam proses pendaftaran dimana ada beberapa mahasiswa yang menyiapkan syarat-syarat sendiri dan ada juga beberapa mahasiswa yang tidak dimintai syarat-syarat yang telah ditentukan.

\section{Keterbatasan Penelitian}

Penelitian ini hanya memiliki delapan orang informan namun delapan orang tersebut satu orang merupakan informan yang tidak lulus beasiswa di daerah Padang. Tidak semua penerima beasiswa Bank Nagari peneliti wawancara. Penelitian ini hanya berdasarkan interpretasi kalimat peneliti sehingga hasil peneliti juga dapat mengalami bias dalam menginterpretasikan data. Oleh karena itu, penelitian ini tidak dapat digeneralisasi terhadap penelitian selanjutnya.

\section{Saran}

Penelitian selanjutnya sebaiknya dilakukan wawancara yang mendalam kepada pihak-pihak yang memiliki peran serta kepentingan terhadap perusahaan tidak hanya orang-orang yang berada di dalam perusahaan dan para penerima program CSR Bank Nagari, akan tetapi ini juga bisa dimintai keterangan dari pemerintah daerah yang ada di Sumatera Barat agar bisa mengurangi bias dalam interpretasi kalimat peneliti. 


\section{DAFTAR PUSTAKA}

Afrizal. (2014). Metode Penelitian Kualitatif. Jakarta. Rajagrafindo.

Annual Report Bank Nagari (2016, 2015, 2014, 2013 dan 2012).

Bappenas. Bab 27 Peningkatan Akses Masyarakat Terhadap Pendidikan yang Berkualitas. www.bappenas.go.id/get-file- server/node/172/. Diakses tanggal 21 November 2017.

BPS Sumatera Barat. Berita Resmi Statistik. https://sumbar.bps.go.id/. Diakses tanggal 10 Desember 2017.

Budi, H.(2008). Corporate Social Responsibility. Jakarta. Sinar Grafika Offset.

Debi, S.C. 2014. Hubungan Motivasi Belajar Dengan Prestasi Belajar Pada Mahasiswa Bidikmisi Jurusan Ekonomi Dan Administrasi. Skripsi. Universitas Negeri Jakarta.

Elkington, J. (1997). Cannibal with Forks, the Tripple Bottom Line of Twentieth Century Business, Capstone Publishing Ltd, London.

Gustian, R. 2018. Implementasi Corporate Social Responsibility (CSR) Di Bank Nagari. Skripsi. Universitas Negeri Padang.

http://fib.bunghatta.ac.id/index.php/id/artikel/90-fakultas-ilmu-budaya. Diakses tanggal 25 November 2018.

Kotler, P. and Nancy, L. (2005). Corporate Social Responsibility : Doing The Most Good For Your Company and Your Cause. Best Practices From Hewlett Packard, Ben \& Jerry's, and Other Leading Companies. Jhon Wiley \& Sons, Inc. United States of America.

Marlia, M.A. 2008. Pentingnya Implementasi Corporate Social Responsibility Pada Masyarakat Indonesia. http://mamrh.wordpress.com/2008/07/21/53. diakses tanggal 12 Desember 2017.

Moleong, L. (2008). Metodologi Penelitian Kualitatif. Bandung. PT. Remaja Rosada Karya. Muhammad, F 2013. Manfaat Beasiswa bagi Pendidikan .Artikel.

Rachmawaty, D.T. 2016. Pengaruh Beasiswa Bidikmisi Terhadap Prestasi Belajar Mahasiswa Penerima Beasiswa Bidikmisi. Skripsi. Universitas Islam Negeri Syarif Hidayatullah Jakarta.

Rochayatun, S. (2017). Dream and nightmare: meraih sustainability melalui corporate sosial responsibility. Jurnal Simposium Nasional XX 2017.

Solihin, I. (2009). Corporate Social Responsibility from Charity to Sustainability, Jakarta. Salemba Empat.

Stefania, I.F. 2008. Implementasi corporate social responsibility (CSR) pada perusahaan di bidang kehutanan dalam pengembangan masyarakat dan perlindungan lingkungan. Skripsi Universitas Atma Jaya Yogyakarta.

Sucipto, A. 2017. Dampak Program CSR PT PLN APJ Jogyakarta Terhadap Peningkatan Kesejahteraan Masyarakat. Skripsi. Universitas Sanata Dharma.

Sugiyono. (2014). Metode Penelitian Kualitatif dan R\&D, Bandung: Alfabeta CV.

Suharto, E. (2010). CSR \& COMDEV, Investasi Kreatif Perusahaan Di Era Globalisasi. Bandung. Penerbit Alfabeta.

Surya, M. (2004). Pendidikan Murah, Mungkinkah? Dalam Pikiran Rakyat 5 Juni. Bandung. PT Percetakan Offset GRANESIA.

Susanto, A.B. 2010. A Strategic Management Approach Corporate Social Responsibility. Jakarta. The Jakarta Consulting Group.

Sustainability Report, 2016. Bank Nagari. http://www.banknagari.co.id/do/annual. Diakses pada 09 November 2017. 
Triyanto, D. 2013. Pelaksanaan Corporate Social Responsibility (CSR) Di Bidang Pendidikan PT. Hino Motors Sales Indonesia. Skripsi. Universitas Negeri Yogyakarta.

Undang-Undang Nomor 40 Tahun 2007 tentang Perseroan Terbatas.

Undang-Undang Republik Indonesia Nomor 21 Tahun 2003 tentang Sistem Pendidikan Nasional. Wibisono, Y. (2007). Membedah Konsep dan Aplikasi CSR. Fascho Publishing: Gresik.

Winara, A. (2010). Buku Panduan Tanggung Jawab Sosial Perusahaan (Corporate Social Responsibility-CSR). Jakarta. Tim Teknis Pembangunan Sanitasi (TTPS).

Zona, N.H. 2013. Bentuk Program Corporate Social Responsibility Bank Nagari Cabang Pangkalan dan Manfaatnya Bagi Kehidupan Sosial Ekonomi Masyarakat Lokal. Skripsi. Universitas Sumatera Utara. 